\title{
Shaping the climate for language shift? English in Sweden's elite domains
}

\author{
E. CATHRINE BERG,* FRANCIS M. HULT** and \\ KENDALL A. KING***
}

\begin{abstract}
This paper investigates how and to what degree English is used in specific elite domains in Sweden through analysis of (1) language requirements to participate in undergraduate and graduate programs at competitive institutions; and (2) language qualifications and language use patterns in elite professions. We find that English is used pervasively, but not exclusively. The paper also explores to what extent these language use patterns in elite domains suggest that language shift toward English in Sweden might take place in the future. Although our data indicate that functional dominance of English is far from complete, we argue that the fact that English holds a prominent position in certain elite domains might be significant in influencing language ideology. Furthermore, whereas Sweden cannot presently be characterized as a nation undergoing language shift, the high status of English as the language of international communication and its significance as an important channel of communication in many elite domains are possibly important factors in shaping the climate for language use patterns of the coming decades.
\end{abstract}

\section{INTRODUCTION ${ }^{1}$}

The expansion of English in Europe in general and in Sweden in particular has received considerable attention in recent years both in this journal (e.g., Deneire and Goethals, 1997) and elsewhere (Boyd and Huss, in press; Skutnabb-Kangas and Phillipson, in press; and Cenoz and Jessner, 2000). These inquiries have focused on topics such as the position of English in the administration of the European Union (Melander, in press), the role of English as a European lingua franca (James, 2000), attitudes toward English (Hyrkstedt and Kalaja, 1998), functions of English (Petzold and Berns, 2000), and the acquisition of English as a third language among European bilinguals (Cenoz and Jessner, 2000). Our focus is related to these topics but is in some ways more specific, targeting language use patterns in particular high-status domains, which may be characterized in some sense as "international," yet are also clearly part of Swedish society.

More specifically, this study examines the relative positions of English and Swedish in what we term elite domains. Within the field of applied linguistics the concept of "elite bilingualism" is sometimes contrasted with that of "folk bilingualism." In this paradigm, elite bilinguals "are usually highly educated, and some part of their education has been in foreign languages" (Skutnabb-Kangas, 1981: 97). Folk bilinguals, in contrast, "have usually been forced to learn the other language in practical contact with people who speak it" (1981: 97). While this distinction is an important one, the concern of the present

\footnotetext{
* Division of English as an International Language, 3070 Foreign Languages Building, 707 S. Mathews Avenue, Urbana, IL 61801, USA. E-mail: ceberg@uiuc.edu

**Steinhardt School of Education, New York University, 239 Greene Street, New York, NY 10003, USA. Email: fmh1983@nyu.edu

***Steinhardt School of Education, New York University, 239 Greene Street, Room 635, New York, NY 10003, USA. E-mail: kendall.king@nyu.edu
} 
paper is not elite bilinguals as individuals, but rather language use in elite domains. Our terminology here derives in part from the observation that each of these domains shares the common characteristic of participating in some manner in the international community, generally through international exchanges of individuals, commercial products, or intellectual goods. More importantly, there is a general consensus that these domains are high status and high prestige, evidenced in part through the highly competitive requirements for entry (e.g. graduation from a selective high school or university program), and the small number of individuals participating in them. Further bolstering this impression is the fact that often, although not always, individuals who are employed in these areas are financially well rewarded.

Elite domains in Sweden are of particular interest for a variety of reasons. Sweden is clearly part of the "Expanding Circle" of countries in which English is widely studied and used, but has a restricted number of institutionalized functions and limited official recognition (Kachru, 1985; 1992). From the perspective of the study of world Englishes, the Swedish situation contributes to our understanding of the power, influence and position of English in non-colonized European states, a topic of recent interest and concern (e.g. Hoffmann, 2000; James, 2000; Jessner and Cenoz, 2000; and Tollefson, 2000). This area of study, in turn, potentially sheds light on the emerging power asymmetry which seems to be growing worldwide between national languages on the one hand and English on the other (Phillipson, 1992; 2000).

Some researchers have suggested that the power asymmetry observed between national languages and English appears to resemble diglossia. ${ }^{2}$ Teleman (1993), for instance, suggests that increasing internationalization in both academics and politics creates an environment in which Swedish becomes subordinate to English, resulting ultimately in a diglossic situation in certain arenas (such as natural science departments in universities). Gunnarson and Öhmann's (1997) work to some extent supports this argument; they found in their study of language use at Uppsala University that English was used pervasively as the language of instruction, course readings and texts, and dissertations. Concurring with Teleman, they note, "the Swedish scientific community is threatened by diglossia [and] . . for example, [in] certain industries and branches of science, there exists reason to fear that a functional division is underway" (p. 74). However, there is less than total agreement on this point. Melander (1987), for instance, is not as quick to agree with the characterization of the Swedish/English language situation as diglossic. While he concedes that a functional differentiation is apparently growing in some domains, he does not foresee a future where Swedish becomes completely subordinated to English, putting the two in the traditional High/Low dichotomy and functional distribution which is characteristic of diglossia.

Nevertheless, from the perspectives of the study of language shift and world Englishes, the sociolinguistic implications of the asymmetrical power relationship between English as an international prestige language and a given national language which holds less prestige, should not be lightly dismissed. Certain aspects of the diglossia paradigm might, in fact, prove useful in characterizing this relationship, a possibility to which we will return later in the paper. It is our hope that such characterization might illuminate how the international uses of English possibly influence the future status of Swedish in Sweden.

The position of Swedish in Sweden is hardly a new area of interest; indeed, both the status and corpus of Swedish have been a subject of government, popular, and academic concern for at least two decades (e.g. Jonsson, 1976; Teleman, 1993; and William-Olsson, 1998a). The most recent and obvious manifestation of this concern is the move by the 
government to develop legislation to support the position of Swedish. In 1997 the government requested that the Swedish Language Council, Svenska Språknämnden, draw up an "action program" for the promotion and protection of Swedish vis-à-vis "foreign" languages, and English in particular. This program, in the form of a report published in 1998 in the Council's publication, Språkvård, is currently being reviewed by a parliamentary sub-committee with a revised version scheduled to be circulated in late Autumn, 2001.

The primary recommendation of the Svenska Spräknämnden report is that the position of the Swedish language in Sweden be established by law. The goal of such legislation, in the view of the Swedish Language Council, should be to preserve Swedish as a "complete language serving the needs of [all sectors of Swedish] society" (1998: 1). This, the report suggests, is of paramount importance to Swedish language planning given the observed intrusion of English into new domains, noting that "the most far-reaching influence consists in English taking over domains in which Swedish once pre-dominated" (1998: 9). Specific proposals address the importance of maintaining the position of Swedish as an official language within the European Union; the need for legislation requiring companies to provide safety and operating instructions of their products in Swedish; and the importance of (re)establishing Swedish as the normal language of primary, secondary, and higher education. Incidentally, the report makes little mention of the impact of its recommendations on Sweden's immigrant and national minority languages or their speakers, a point which has drawn attention and criticism (e.g. Boyd and Huss, 2000). ${ }^{3}$

The focus of our interest, like that of the Swedish Language Council, is on the status of Swedish. As several researchers (e.g. Hyltenstam, 1999; Teleman, 1992; and Westman, 1996) have indicated, any potential threat to Swedish by English is almost certainly at the level of language function. In other words, the real danger for the language is the potentially expanding domains of English, and corresponding contracting domains of Swedish. Indeed, Hyltenstam (1999) - not unlike Teleman (1993) - has warned that Swedish and English are settling into a kind of minority/majority language configuration in Sweden. Hyltenstam warns that in the foreseeable future, Swedish might become more and more like an informal, intimate-sphere language, and in the course of time English might become the leading language of Swedish society. This, according to Hyltenstam, could lead to greater inequality as proficiency in a foreign language would then serve as a prerequisite for success in society (1999).

With this potential for inequality, and in particular for differentiated access to highstatus domains in mind, a central aim of this paper is to explore the language skills needed to access and participate in elite levels of commerce and academic study. This issue is of importance for at least three reasons. First, based on other cases of language shift in the literature (e.g. Garzon, 1992; Mesthrie and Leap, 2000; and Rhodes, 1992) which suggest that the public, formal, and high-status domains are the first to be allotted to the new language, a shift towards English, if it is indeed occurring in Sweden, is likely to be most visible in Sweden's elite domains. In other words, if language shift is underway, it is likely to be most advanced and most measurable here. Second, we reason that requisite mastery of English for participation in these high-status domains provides incentives for English to be stressed in other (lower-status) domains, such as elementary and secondary education. In other words, widespread use of English would perhaps be most influential in elite domains because of their prominence and appeal for the rest of society. Third and finally, elite domains provide a means of analyzing the role of English as an international language, as well as examining the usefulness of the concept of diglossia to adequately 
describe the asymmetrical relationship between English on the one hand, and national languages such as Swedish on the other. Our overarching questions then, are as follows: (1) How and to what degree is English used in specific elite domains in Sweden? and (2) To what extent do the language use patterns in elite domains suggest language shift toward English in Sweden?

\section{METHODS AND FINDINGS}

To address these issues, we examined language use patterns through a range of data collection techniques in four arenas, each of which is generally assessed as elite in terms of status, financial compensation, or both. These areas of investigation include (1) the language skills required to participate in undergraduate courses at one of the most academically competitive universities (in terms of admission standards) of higher education in Sweden; (2) the language of doctoral dissertations at Stockholm University; (3) the language qualifications for high-level positions in computer technology and business; and (4) perceptions of language use among professionals at companies in the areas of accounting, information technology, pharmaceuticals, communications, and packaging. Further description of each follows below.

\section{Language in courses at the Stockholm School of Economics}

The Stockholm School of Economics (Handelshögskolan i Stockholm) is the most competitive undergraduate university for the study of business, finance, and economics in Sweden: each year approximately 4,000 applicants compete for the 300 places available; and the grades needed for admission are the highest required by academic institutions in Sweden. All undergraduate students complete a four-year program of study which awards an undergraduate degree and a Masters of Science. For the first two years, all students take a nearly identical program of study, and all courses during these first two years are offered only in Swedish. During their final two years of study, students choose from electives within their majors. Some of these specialized courses are offered only in Swedish; others are offered only in English.

In our review of these elective courses we found that of the 122 elective courses offered during the 1999-2000 academic year, 52 (43\%) were offered in English; 70 (57\%) were offered in Swedish. Perhaps more significantly, we also found that the language of these specialized electives is not uniform across majors. Examination of the courses offered during the Spring 2000 term, for instance, indicates that English is essential for some majors, but not necessary for others. For example, students who majored in organizational leadership and accounting were only offered courses in Swedish. Marketing and economics majors, in comparison, could choose from courses either in Swedish or English; 50\% of economics courses were offered in English, while 36\% of marketing electives were taught in English. In contrast, the major which promises the highest salaries upon graduation, finance (J. Heathcote, personal communication, July, 2000), offered all of its courses only in English. As has been found elsewhere (cf. Dogançay-Aktuna, 1998), it appears that the most lucrative areas of study - in terms of wages upon graduation and employment - are those which require individuals to use English extensively.

A further point which merits mention is that it is likely that this measure does not fully reflect the importance of English skills for students at the Stockholm School of Economics. In other words, even courses which are ostensibly offered in Swedish frequently make use of 
English language text books. Indeed, analysis of the books ordered for all academic courses at the School for the Spring 2000 term reveals that 131 of $230(57 \%)$ were English language texts. This is the case despite the fact that the great majority of students and instructors are native Swedish speakers (J. Heathcote, personal communication, February, 2001).

\section{Language of doctoral dissertations at Stockholm University}

The second elite area which we analyzed was the language of doctoral dissertations at Stockholm University, one of the most important research institutes in Sweden. Specifically, we examined the language of publication across five disciplines (chemistry, biology, psychology, linguistics, and philosophy) over a period of two decades, at four-year intervals (1978; 1982; 1986; 1990; 1994; 1998).

As is clear from a review of table 1, in the natural sciences (chemistry and biology), there has been no change in the last two decades: since 1978 all dissertations (roughly 20 a year in each field) have been published in English. In psychology, there has been relatively little change over time; each year roughly half of the Ph.D. dissertations are published in English. In philosophy and linguistics, in contrast, there appears to possibly be a gradual increase in English language dissertations (as well as overall numbers of dissertations) since 1978. In recent years, approximately half of the doctoral dissertations have been presented in English.

Studies from other major universities in Sweden confirm most aspects of the Stockholm data, in particular the much greater use of English in the natural sciences than in the arts and humanities. Teleman (1992), for instance, reports in his analysis of the language of doctoral dissertations at Lund University in 1991 that $100 \%$ of those in the areas of dentistry, medicine, math and natural sciences were published in English. In contrast, fewer than $50 \%$ (11 of 24) of humanities and social science dissertations were published in English. Gunnarsson and Öhmann's (1997) work also supports the Stockholm University findings. Their study at Uppsala University found that English was used to a greater or lesser extent at nearly every level of the university. Furthermore, as also seems to be the case at Stockholm University, while English is used to some degree within all disciplines of the university, it is most common in technical and scientific fields.

\section{Language qualifications in job announcements}

Whereas the use of English in these elite educational areas provides an important perspective, it is also of interest to estimate what sorts of language skills were expected

Table 1. Number (and percent) of Stockholm University dissertations in English by year and discipline

\begin{tabular}{rrrrlll}
\hline & Biology & Chemistry & Psychology & Linguistics & Philosophy & TOTAL \\
\hline 1978 & $23(100)$ & $25(100)$ & $6(55)$ & $0(0)$ & $0(0)$ & 54 \\
1982 & $3(100)$ & $11(100)$ & $2(50)$ & $1(50)$ & $2(50)$ & 19 \\
1986 & $17(100)$ & $25(100)$ & $3(60)$ & $1(50)$ & $1(33)$ & 47 \\
1990 & $27(100)$ & $29(100)$ & $9(47)$ & $1(50)$ & $3(100)$ & 69 \\
1994 & $19(100)$ & $22(100)$ & $13(68)$ & $4(66)$ & $5(42)$ & 63 \\
1998 & $21(100)$ & $28(100)$ & $9(50)$ & $4(66)$ & $3(50)$ & 65 \\
\hline
\end{tabular}


among the graduates of such programs who are vying for elite professional positions. In order to measure the levels of English competency explicitly required for these positions, 781 employment advertisements were examined. All of the announcements appeared in Nytt Jobb, December 13, 1999 (no. 50), which is published weekly by the state employment agency (Arbetsförmedlingen) and distributed at Stockholm University and elsewhere in large numbers. Two sorts of elite job announcements were selected: (1) Teknik/Data (information and computer technology); and (2) Ekonomi/Administration (business/administration). We chose these areas because interviews with employment counselors at Stockholm University indicated that these two areas were by far the highest paying and among the most popular (in terms of student interest and preference) fields of employment, a fact which was further supported by informal conversations with university students and recent graduates.

Our analysis revealed that of the 434 advertised jobs under Teknik/Data (information and computer technology), 72 explicitly required proficiency or fluency in English. A further 11 of these jobs were listed in English, thus suggesting that non-English speakers need not apply. In total, 19\% of the jobs advertised in the area of information and computer technology required proficiency or fluency in English. The picture is quite similar in the area of business/administration. Here, we found that of the 347 positions advertised, 43 explicitly required proficiency or fluency in English; a further 11 of the 347 were listed entirely in English. Thus, in total, $16 \%$ of the positions advertised in the business/administration area demanded fluency or proficiency in English.

In comparison with other recent studies of the market value of English in obtaining competitive positions, the English requirements in Sweden appear relatively modest. For example, Dogançay-Aktuna (1998) found in her analysis of language requirements among jobs advertised in major Turkish newspapers that $55 \%$ of the job openings required competence in a foreign language. Of these, $87 \%$ required knowledge of English. Dogançay-Aktuna furthermore notes that "the higher level, better-paid white collar positions in well-known companies" tended to specify English as a job requirement, while "the lower level, blue collar jobs . . . did not seem to mention English most of the time" (p. 34). It is also important to note, however, that in Sweden this measurement possibly underestimates the importance of English as a job requirement. That is, as English is often viewed as essential in some professions and competence in the language is frequently assumed by employers, explicit mention of this requirement might not be not perceived as necessary (K. Hyltenstam, personal communication, March, 2000).

\section{English in the workplace}

Whereas employment announcements provide a glimpse of official requirements, they do little to illuminate to what extent English is in fact used and needed on the job. To tap into prevailing perceptions of language use in general and the use of English in particular at elite workplaces in Sweden, 33 employees at five different randomly selected companies were surveyed concerning language use patterns at their workplaces. Questionnaire respondents - with the exception of one executive secretary - all held high-level, professional positions such as accountants, account managers, computer experts, or marketing directors. The five companies were businesses in the areas of accounting, information technology, pharmaceuticals, communications, and the packaging industry, all of which are extensively engaged in international commerce. 
Questionnaires were conducted in Swedish via e-mail over a nine-month period in 1999-2000, and included ten main question areas ranging from basic personal information such as age, gender, and position to specific questions about language policies at the company. (See Appendix for an English translation of the questionnaire.) Most questions were of a short answer or multiple choice type with space for comments and elaboration. With the exception of one initial contact person at each workplace, respondents were selfselected (that is, they volunteered to participate). Swedish was the only native language of 31 of the 33 respondents, one respondent spoke German natively and Swedish at an intermediate level, and another grew up as a Swedish-Finnish bilingual. Most co-workers were reported to be native Swedish speakers or having near-native proficiency in Swedish. All responses were included in the final tabulation of results.

The questionnaires revealed a number of thought-provoking findings, but for reasons of space our report is limited to the following five areas: perceptions of (1) languages used (written and spoken) on a daily basis at the workplace; (2) languages used (written and spoken) in formal versus informal contexts; (3) languages used (written and spoken) in relation to a particular topic; (4) patterns of use for individual speakers in a given communication event; and (5) perceived changes in language use at the workplace.

Concerning what languages are used on a daily basis in the workplace, each of the 33 respondents reported that he or she used Swedish every day. Importantly, 22 respondents $(67 \%)$ indicated that they also used English every day. Thus, although Swedish must be seen as the main language of the workplace, English was perceived by a clear majority of respondents as prevalent enough in their work to be part of everyday communication.

In terms of the languages used in formal versus informal contexts, we found that across both of these contexts, whether or not a non-Swedish speaker was present seemed to be a major factor in determining language use patterns. Indeed, the presence of one non-fluent speaker of Swedish seemed to act as a "trigger" to switch to English. In turn, by far the most common language practice when all Swedish speakers were present was to use only or mostly Swedish irrespective of context (formal versus informal) or mode (spoken versus written) of communication. For instance, in formal meetings in which all participants are fluent Swedish speakers, respondents indicated that "mostly" (18\%) or "only" (81\%) Swedish would be spoken. In contrast, in formal meetings where someone is present who does not have a good command of Swedish, respondents noted that "mostly" $(67 \%)$ or "only" (18\%) English would prevail.

In terms of written communication, we see a slightly different pattern. Respondents noted that for formal written communication (e.g. reports, memos, letters) involving one or more recipients who does not have a strong command of Swedish, "only" (64\%) or "mostly" (33\%) English would be used. Responses concerning language use for the same type of correspondence but directed only at fluent speakers of Swedish were divided among responses of: "only Swedish" (27\%), "mostly Swedish" (30\%), "mostly English" (27\%), "Swedish and English equally" (12\%), and "only English" (3\%). Furthermore, in their comments, several employees indicated that English was the "official" or the "unofficial" language of the company and therefore should be used in formal written communication. One respondent observed that "more international communications, especially written documents are increasingly written in English" [translation ours]. Another respondent went on to explain a possible reason for this trend: "often an issue ultimately gets forwarded to a person(s) who does not speak Swedish and then it's simpler to begin communication about it in English (unofficial policy)" [translation ours]. Informal written 
communication patterns, in comparison, tended to lean slightly more towards Swedish. For instance, for e-mails and short notes among fluent Swedish speakers, most respondents noted that "only Swedish" would be used (87\%).

Turning now to the languages used in relation to particular topics, such as computers, company products or activities, and international issues, we find that English is most often used to discuss international issues such as trade or currency exchange. Indeed, 56 percent of respondents reported that the language for these discussions was "usually English," while considerably fewer reported that "usually Swedish" (21\%) or "Swedish and English equally" (21\%) were used. In contrast, for conversations about computers, respondents noted that Swedish and English would likely be used equally $(56 \%)$, with many also reporting that usually Swedish $(30 \%)$ or usually English $(12 \%)$ would be used. Similarly, for discussions concerning company products or activities, responses were divided among "usually Swedish" (30\%), "Swedish and English equally" (36\%), and "usually English" $(33 \%)$. Overall, an equal use of Swedish and English was the most common response for all three topic areas surveyed (computers, company products or activities, and international issues), with the possible exception of international issues where most people reported English to be their language of choice. It is interesting to note that no respondent held that Swedish was the only language used to discuss issues within any of these three given topic areas.

Consistent with these findings, examination of respondents' perceptions of individual language use patterns in all contexts indicates the predominance of code-switching or codemixing. Relatively few respondents $(18 \%)$, for instance, reported that it was common for an entire conversation to proceed only in Swedish or only in English. Indeed, more than half of the respondents $(52 \%)$ noted that it was common for an individual - within one sentence - to speak mostly in Swedish, but use some English words. In contrast, no one reported that the reverse was true - that is, speaking mostly English with the use of some Swedish words. Many respondents (60\%) also noted that it was common for an individual to use only Swedish in one conversation, and only English in another.

Lastly, turning to perceptions of recent changes in language use in the workplace, responses present an uneven picture. Sixty-one percent of those surveyed indicated that they had noticed no change in language use patterns. Nine percent did not know or did not respond. Thirty percent responded that they had noticed a shift away from Swedish in recent years; most stated that this shift had been towards English although three respondents - all of whom worked in a company which was recently acquired by a German corporation - indicated that the shift had been towards German. Considering the short length of employment for many respondents (more than half had been there for fewer than ten years), changes in language use might not be visible to them. Thus, whereas it seems clear that a rapid change is probably not underway in most elite Swedish companies, a gradual change might well be. In fact, Hollqvist's (1984) survey of the use of English at three large international companies in Sweden (Svenska Handelsbanken, LM Ericsson, and Scandinavian Airlines System) indicates that English, already by the mid1980s, held a prominent position at those companies. However, in comparing results of the use of English on a daily basis, for example, we find that only 27 percent of Hollqvist's 268 respondents (all of whom occupied administrative, business, trade, research, development, or personnel positions with approximately half being university graduates) used English every day. Despite the discrepancy in number of respondents and educational levels, Hollqvist's 27 percent is a much lower number than the 67 percent in our sample who 
reported using English on a daily basis. This difference in use of English on a daily basis from the mid-1980s to year 2000 might suggest a shift in language use.

\section{DISCUSSION}

It is now appropriate to ask how the data presented above help answer the two questions presented in the introduction: (1) How and to what degree is English used in specific elite domains in Sweden? and (2) To what extent do the language use patterns in elite domains suggest language shift toward English in Sweden?

Turning first to the question concerning the extent of English use in elite domains, we find that the picture is difficult to summarize neatly. For instance, English clearly does not dominate - or even come into use - in all elite domains in Sweden. As an example, one could - with apparently little need for English - attend the Stockholm School of Economics with a major in organizational leadership and accounting. Upon graduation, one could apply for one of the jobs in the area of business and economics. (Eighty-four percent of professional positions in these fields did not specify English as a requirement.) Furthermore, while our questionnaire data indicate that Swedish remains the primary language of communication for both spoken and written interactions, English is also used extensively in many of these elite domains. Indeed, not unlike the two-tiered society which Hyltenstam (1999) suggested as a possible scenario, English proficiency is essential for unrestricted access to elite educational and occupational arenas. For instance, if one wants to go into the high-status, highly compensated area of finance at the Stockholm School of Economics, English is essential. Likewise, if one wishes to participate at the graduate level in the natural science fields, high levels of English competency are critical. Thus, although English is not the only or even the primary language used in these elite domains, it is nonetheless used pervasively and critical to gaining access to - and fully participating in many of them. Thus, based on our limited review, it appears that Hyltenstam's (1999) concern regarding the development of a two-tiered society, where competence in English is essential for participation in certain elite domains, is not unrealistic. English seems to have made wide inroads into many, if not all, elite domains.

These patterns, while far from clear or definite, have implications for societal-level language use patterns, which brings us to the second question of the paper: the implications of these findings for language use and potentially language shift in Sweden. The prevalence of the use of English in elite domains intersects with and likely influences language use in other national arenas. In certain elite domains, such as those discussed here, we see that English is a frequently used code. As noted above, this widespread use of English in certain domains has led some academics (e.g. Teleman, 1993; Teleman and Westman 1997; and Westman, 1996) to question whether some sort of diglossic situation or perhaps even language shift might be developing in Sweden.

Hudson-Edwards (1984), however, has warned that the term diglossia has come to be used in a rather imprecise manner and consequently there is a risk that it will lose its validity as a useful construct. And indeed, based on the data presented here it is evident that labeling the currently observed relationship between Swedish and English in Sweden as diglossic is problematic. Perhaps most important in this regard is the fact that there is not a clear differentiation of language function: English seems to have a prominent position in many of these elite arenas, but by no means is it used to the exclusion of Swedish. Rather these arenas are characterized by varied use of both English and Swedish. 
A second problem with categorizing the Swedish case as diglossic is that the present situation is relatively new. While the English influence was already apparent by the 1930s (Haugen, 1990), by most accounts (e.g. Melander, in press), English did not begin to expand significantly in Sweden until after the Second World War. This time frame is less than the three generations generally considered necessary for stable diglossia to develop (Fishman, 1980).

Yet although it would be inaccurate to label the present relationship between Swedish and English in Sweden as diglossic, the asymmetrical power relationship between these two languages should not be overlooked. As our data demonstrate, the elite domains of Sweden, are an environment in which language choice boundaries are currently being negotiated, as evidenced by the varied use of both English and Swedish. In this vein, it is telling that according to our questionnaire data language choice was often based on accommodation to non-Swedish-speaking interlocutors, suggesting that there is a tendency to defer Swedish to English. Given the high international prestige which English carries and its apparently growing prominence in elite domains, one might view English and Swedish as existing in a state of "pre-diglossia." This state of "pre-diglossia" might, if English continues to feature heavily in elite domains over subsequent generations, lead to sharper functional differentiation between the two languages, and eventually to diglossia or potentially language shift towards English.

Eckert (1980) and Schiffman (1993) have illuminated the complex nature of diglossia, and suggested that, contrary to its delineation in early formulations (e.g. Ferguson, 1959; and Fishman, 1967), it is not necessarily stable, but rather can serve as a vehicle for language shift as power asymmetries between two languages grow. However, it is also relevant to question whether language shift is in fact feasible in a case like Sweden, where, after all, only a limited number of people compete at the elite levels examined here. For instance, Sweden is a country of more than 8 million, yet the Stockholm School of Economics takes fewer than 300 students each year. In response to this concern, it should be noted that diglossia need not exist within a society as a whole; instead it is possible for only certain speakers or segments of society to exhibit diglossic language use patterns (Schiffman, 1993). Thus, elite domains in Sweden might be viewed as the frontline of future language shift, with the potential to influence other domains of society. This is not an unimportant point as English use in elite domains holds the possibility of shaping the language ideology of Swedes and influencing language use patterns within non-elite or semi-elite domains. It is well documented that "the promise of socioeconomic mobility" has led many people to abandon their native languages in favor of a more prestigious and economically powerful variety (Eckert, 1980: 1055). Along these lines, scholars such as Ljung (1986) have suggested that English might well be "seeping into" non-elite domains.

Anecdotally, evidence seems to suggest that this might be happening to some extent already. For instance, the last decade has witnessed a dramatic growth in the instruction of English in early grades: in 1991, about 30 municipal schools in Sweden began English instruction in Grade One; by 1999, this number had jumped to 1,411 (Laino, in press). Furthermore, there appears to be an increasing number of elementary and secondary schools that not only regularly instruct English as a subject but offer it as a medium of instruction for some content area courses (William-Olsson, 1998b). While not without criticism or controversy (e.g. Gunnarson, in press), there seems to be a growing trend towards experimenting with these English-based curricula. Many such programs are in great demand, perhaps in part because they are perceived to give their students a 
competitive edge and a greater chance of admission into elite, high-status universities and professions.

It is critical, then, to consider not only the actual demand for or necessity of English, which our data indicate is in some respects quite limited at this juncture, but the perceived need and value of the language. In other words, although our data suggest that functional dominance of English is not overwhelming at this point, the fact that English does hold a prominent position in certain elite domains might well be significant in influencing public opinion, language ideology and ultimately, language behavior. There is some evidence that such a shift in ideology is already taking place; Wingstedt (1998), for instance, in her largescale survey of language ideology in Sweden finds that whereas many of her respondents viewed competency in indigenous and immigrant languages negatively, English was the exception to this rule. In her words, "while the 'metropolitan languages' (in practice, English) have begun to encroach on the Swedish arena to an extent never seen before, these languages and the variety of proficiency in them appear to constitute 'acceptable difference" " and hence are viewed very favorably (p. 327).

\section{CONCLUSION}

Functions of English in Sweden are more clearly different today than just 20 years ago. For example, English is pervasively used in academia, its role at the workplace appears more prominent, it is introduced as a school subject in lower grades, and it is the medium of instruction in certain high schools. What is less clear is how the present state of English vis-à-vis Swedish in Sweden can best be described. As discussed above, our data suggest that diglossia is not the most accurate characterization of Sweden's current sociolinguistic circumstances. Given the present situation in Sweden, one might instead consider the work of Nancy Dorian. In her classic text on language shift among speakers of East Sutherland Gaelic (1981), Dorian suggests that although shift often seems to take place very quickly over just one or two generations, the sociocultural-attitudinal climate which leads up to that shift can be centuries in the making. She notes that whereas the "tip" toward English was sudden, within the national context, "the forces and attitudes which led to the tip had long been felt" (1981: 70).

Despite the fact that most people in Sweden are not required to use English on a day-today basis (as stressed above, the numbers participating in these elite domains appear to be relatively few), the prestige and visibility of English, and the perceived need of English seem to be great. We suggest that the seemingly widespread and entrenched use of English in Sweden's elite domains is significant. While Sweden cannot be characterized as a nation presently undergoing language shift, the high status of English as both the language of international communication and an important code of communication in many elite domains, might be important in shaping the climate for language shift and hence in influencing language use patterns of the coming decades.

\section{APPENDIX: ENGLISH TRANSLATION OF QUESTIONNAIRE DISTRIBUTED TO SWEDISH EMPLOYEES}

1. Are you male or female?

Male

Female 
2. How old are you?

3. What is your professional title at your present workplace? For how long have you had this position?

4. Which languages are used daily (orally or in writing) at your work?

5. Which language is used in the following communicative situations at your work?

5a) Formal gatherings:

If a person who does not master Swedish well is present, we normally speak Swedish only mostly Swedish as much Swedish as English mostly English English only other language (which one/s ?)

If only Swedish speaking people are present, we normally speak Swedish only mostly Swedish as much Swedish as English mostly English English only other language (which one/s ?)

5b) Informal social gatherings (for example at coffee breaks, during informal chats, etc.):

If a person who does not master Swedish well is present, we normally speak Swedish only mostly Swedish as much Swedish as English mostly English English only other language (which one/s ?)

If only Swedish speaking people are present, we normally speak Swedish only mostly Swedish as much Swedish as English mostly English English only other language (which one/s ?)

5c) Formal written communication (for example internal e-mails, messages, etc.):

If a person who does not master Swedish well is present, we normally use Swedish only mostly Swedish as much Swedish as English mostly English English only other language (which one/s ?)

If only Swedish speaking people are present, we normally use Swedish only mostly Swedish as much Swedish as English mostly English English only other language (which one/s ?)

5d) Informal written communication (for example private e-mails, notes, etc.): 
If a person who does not master Swedish well is present, we normally use Swedish only mostly Swedish

a much Swedish as English

mostly English

English only

other language (which one/s ?)

If only Swedish speaking people are present, we normally use Swedish only

$\square$
mostly Swedish
as much Swedish as English
mostly English
English only
other language (which one/s ?)

6. Is Swe $\overline{\text { dish or }}$ English the language used when treating the following subjects: (Choose "mostly Swedish", "mostly English", or "about as much Swedish as English" for each subject):

Computers: mostly Swedish mostly English

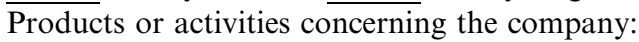
about as much Swedish as English

\section{Products or activities conctis
mostly Swedish} mostly English — mostly English mostly English about as much Swedish as English

\section{International issues:
mostly Swedish
High technology issues:
mostly Swedish
Other issues such as: \\ International issues:
mostly Swedish
High technology issues:
mostly Swedish
Other issues such as: \\ International issues:
mostly Swedish
High technology issues:
mostly Swedish
$\overline{\text { Other issues such as: }}$} mostly Swedish mostly English about as much Swedish as English

\section{Other issues such as:} mostly Swedish mostly English about as much Swedish as English

Other issues such as: mostly Swedish mostly English about as much Swedish as English about as much Swedish as English 7. Which of the following alternatives best describes the use
communicative situations at your work?
everyone uses either only Swedish or only English

_

— the same person can on one occasion use Swedish and on another English

_ a person can in the same sentence use mostly Swedish but with some words in English

_ a person can in the same sentence use mostly English but with some words in Swedish other alternative:

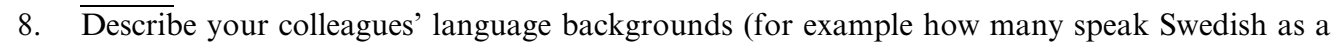
second language?)

9. Do you know if there is an official language policy at your work? yes no

If you answered yes, describe the policy briefly:

10. Have you noticed any change in how different languages are used at your work place? yes

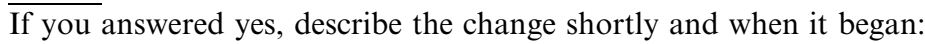

11. Other comments that may help us understand the language use (especially the use of English and Swedish) at your work place: 


\section{NOTES}

1. The authors wish to thank Fred Davidson and two anonymous reviewers for their detailed suggestions on an earlier draft of this paper.

2. A detailed discussion of diglossia (Ferguson, 1959; Fishman, 1967) is beyond the scope of this article. See Hudson-Edwards (1992) for a thorough review.

3. One important line of criticism of the document concerns its focus "on Swedish alone and its status in regard to English, and the neglect of policy recommendations regarding languages other than Swedish [which] make the document potentially damaging both to the new, slightly more secure position of [nationally recognized] minorities in the country and to the large number of "unprotected' mother tongues not accorded this status" (Boyd and Huss, 2000).

\section{REFERENCES}

Boyd, Sally and Huss, Leena (2000) En helhetssyn på språken i Sverige behövs! Multiethnica, 26-7, 14-17.

Boyd, Sally and Huss, Leena (in press) Introduction. In Promoting Multilingualism in a European Nation-state: Challenges for Sweden. Edited by L. Huss and S. Boyd. Clevedon: Multilingual Matters.

Cenoz, Jasone and Jessner, Ulrike (eds.) (2000) English in Europe: The Acquisition of a Third Language. Clevedon: Multilingual Matters.

Deneire, Marc G. and Goethals, Michaël (eds.) (1997) Special issue on English in Europe. World Englishes, 16(1).

Dogançay-Aktuna, Seran (1998) The spread of English in Turkey and its current sociolinguistic profile. Journal of Multilingual and Multicultural Development, 19(1), 24-39.

Dorian, Nancy (1981) Language Death. Philadelphia, PA: University of Pennsylvania Press.

Eckert, Penelope (1980) Diglossia: separate and unequal. Linguistics, 18, 1053-64.

Ferguson, Charles, A. (1959) Diglossia. Word, 15, 325-40.

Fishman, Joshua (1967) Bilingualism with and without diglossia; Diglossia with and without bilingualism. Journal of Social Issues, 23(2), 29-38.

Fishman, Joshua (1980) Bilingualism and biculturalism as individual and societal phenomena. Journal of Multilingual and Multicultural Development, 1, 3-15.

Garzon, Susan (1992) The process of language death in a Mayan community in Southern Mexico. International Journal of the Sociology of Language, 93, 53-66.

Gunnarsson, Britt-Louise (in press) Swedish tomorrow - A product of the linguistic dominance of English? In Promoting Multilingualism in a European Nation-state: Challenges for Sweden. Edited by L. Huss and S. Boyd. Clevedon: Multilingual Matters.

Gunnarsson, Britt-Louise and Öhmann, Katarina (1997) Det internationaliserade universitetet: En studie av bruket av engelska och andra främmande språk vid Uppsala universitet. Uppsala University.

Haugen, Einar (1990) Danish, Norwegian and Swedish. In The World's Major Languages. Edited by B. Comrie. New York: Oxford University Press, pp. 157-79.

Hoffmann, Charlotte (2000) The spread of English and the growth of multilingualism with English in Europe. In English in Europe: The Acquisition of a Third Language. Edited by Jasone Cenoz and Ulrike Jessner. Clevedon: Multilingual Matters, pp. 1-21.

Hollqvist, Håkan (1984) The use of English in three large Swedish companies. Studia Anglistica Upsaliensia 55.

Hudson-Edwards, Alan (1984) Rediscovering diglossia. Southwest Journal of Linguistics, 10, 5-15.

Hudson-Edwards, Alan (1992) Diglossia: A bibliographic review. Language in Society, 21, 611-74.

Hyltenstam, Kenneth (1999) Svenska i minoritetsspråksperspektiv. In Sveriges Sju Inhemska Språk - Ett Minoritetsspråksperspektiv. Edited by Kenneth Hyltenstam. Lund: Studentlitteratur, pp. 205-40.

Hyrkstedt, Irene and Kalaja, Paula (1998) Attitudes toward English and its functions in Finland: A discourseanalytic study. World Englishes, 17(3), pp. 345-57.

James, Allan, R. (2000) English as a European lingua franca: Current realities and existing dichotomies. In English in Europe: The Acquisition of a Third Language. Edited by Jasone Cenoz and Ulrike Jessner. Clevedon: Multilingual Matters, pp. 22-38.

Jessner, Ulrike and Cenoz, Jasone (2000) Expanding the scope: Sociolinguistic, psycholinguistic and educational aspects of learning English as a third language in Europe. In English in Europe: The Acquisition of a Third Language. Edited by Jasone Cenoz and Ulrike Jessner. Clevedon: Multilingual Matters, pp. 248-60.

Jonsson, Inge (1976) Vad händer med svenska språket? Svenska Akademin. Stockholm: Bokförlaget Pan/ Norstedts.

Kachru, Braj B. (1985) Standards, codification, and sociolinguistic realism: The English language in the outer circle. In English in the World: Teaching and Learning the Languages and Literatures. Edited by Randolf Quirk and Henry Widdowson. Cambridge: Cambridge University Press, pp. 11-30.

Kachru, Braj B. (1992) The second diaspora of English. In English in its Social Contexts: Essays in Historical Linguistics. Edited by T. W. Machan and C. T. Scott. New York: Oxford University Press, pp. 230-52. 
Lainio, Jarmo (in press) The protection and rejection of minority and majority languages in the Swedish school system. In Promoting Multilingualism in a European Nation-state: Challenges for Sweden. Edited by Leena Huss and Sally Boyd. Clevedon: Multilingual Matters.

Ljung, M. (1986) Hur ser det ut? Undersökning Engelskan i Sverige. Språkvård,1, 5-10.

Melander, Björn (1987) Det små språken i den europeiska gemenskapen. Språk och Stil, 7, 91-113.

Melander, Björn (in press) Swedish, English, and the European Union. In Promoting Multilingualism in a European Nation-state: Challenges for Sweden. Edited by L. Huss and S. Boyd. Clevedon: Multilingual Matters.

Mesthrie, Rajend and Leap, William, L. (2000) Maintenance, shift and death. In Introducing Sociolinguistics. Edited by R. Mesthrie, J. Swann, A. Deumert, and W. Leap. Philadelphia, PA: John Benjamins Publishing Company, pp. 248-78.

Petzold, Ruth and Berns, Margie (2000) Catching up with Europe: Speakers and functions of English in Hungary. World Englishes, 19(1), pp. 113-24.

Phillipson, Robert (1992) Linguistic Imperialism. Oxford: Oxford University Press.

Phillipson, Robert (2000) English in the new world order: Variations on a theme of linguistic imperialism and 'world' English. In Ideology, Politics and Language Policies: Focus on English. Edited by Tom Ricento. Amsterdam: John Benjamins, pp. 87-106.

Rhodes, Richard (1992) Language shift in Algonquian. International Journal of the Sociology of Language, 93, 87-92.

Schiffman, Harold (1993) The balance of power in multiglossic languages: Implications for language shift. International Journal of the Sociology of Language, 103, 115-48.

Skutnabb-Kangas, Tove (1981) Bilingualism or Not? The Education of Minorities. Clevedon: Multilingual Matters.

Skutnabb-Kangas, Tove, and Phillipson, Robert (in press) The world came to Sweden - but did language rights? In Promoting Multilingualism in a European Nation-state: Challenges for Sweden. Edited by Leena Huss and Sally Boyd. Clevedon: Multilingual Matters.

Swedish Language Council (1998) Draft Action Programme for the Promotion of the Swedish Language. Stockholm: Swedish Language Council.

Teleman, Ulf (1992) Det svenska riksspråkets utsikter i ett integrerat Europa. Språkvård, 4, 7-18.

Teleman, Ulf (1993) Det svenska riksspråkets utsikter i ett integrerat Europa. Språk $i$ Världen: Broar och Barriärer, 127-41.

Teleman, Ulf and Westman, Margareta (1997) Behöver Sverige en nationall språkpolitic? Språkråd $i$ Norden.

Tollefson, James, W. (2000) Policy and ideology and the spread of English. In The Sociopolitics of English Language Teaching. Edited by Joan Kelly Hall and William G. Eggington. Clevedon: Multilingual Matters, pp. 7-21.

Westman, Margareta (1996). Har svenska språket en framtid? In Svenska i tusen år. Edited by L. Moberg and M. Westman. Stockholm: Norstedts, pp. 182-94.

William-Olsson, M. (1998a) Svenska Språket och demokratin hotas av engelskans intrång. Göteborgsposten, 4 Oktober, 52.

William-Olsson, M. (1998b) Här läser de inte bara engelska på engelska. Göteborgsposten, 4 Oktober, 52.

Wingstedt, Maria (1998) Language Ideologies and Minority Language Policies in Sweden: Historical and Contemporary Perspectives. Stockholm University: Centre for Research on Bilingualism.

(Received 14 March 2001.) 
